\title{
Observations on the biting activity of Anopheles triannulatus bachmanni from the Mato Grosso, Brazil.
}

\author{
J. Derek Charlwood ( $\left.{ }^{*}\right)$ \\ Tony J. Wilkes $\left({ }^{* *}\right)$
}

\begin{abstract}
Anopheles triannulatus bachmanni biting man were collected at Aripuana, Mato Grosso. In paired catches less than $5 \%$ of the insects were coliected biting inside houses, most insects were collected at the edge of the rain forest at sunset. Physiological age determination indicated an even age distribution in the females but the insects flight behaviour would make it of little importance as a vector of malaria.
\end{abstract}

\section{INTRODUCTION}

Many species of anophelines in Brazil are suspected secondary vectors of malaria. Their exact vectorial potential is unknown because of the lack of information concerning their behaviour and data, where it exists, is often contradictory. Thus Deane et al. (1946) did not find any Anopheles triannulatus Neiva \& Pinto infected with oocytes and were of the opinion that this was partly because the species" rarely enters houses to feed". More recently Gorham et al. (1967) stated that this species "readily bites man inside houses at ail hours of the day or night".

It is now known that the taxon A. triannulatus can be divided into two subspecies according to certain morphological characters, A. triannulatus s. str. and the larger A. triannulatus bachmanni (=davisi) (Forattini, 1962). Earlier investigators did not differentiate between these two subspecies and this may account for the discrepancy in their results. A. triannulatus s./. has been found naturally infected with sporozoites in Venezuala (CoviaGarcia, 1951), is a suspected vector of simian malaria in Brazil (Deane \& Ferreira Neto, 1973) and is regarded by Forattini as an anopheline that merits further study.
Flight behaviour, longevity and the propensity to enter houses are important influences on vector potential. This paper gives the results of a preliminary study of these factors for a population of A. triannulatus bachmanni from the state of Mato Grosso, Brazil. It also reports a high level of adult infection with an unidentified fungal parasite resembling Coelomomyces.

\section{METHODS}

The study took place in the village of Aripuana $\left(10^{\circ} 19^{\prime} 42^{\prime \prime} \mathrm{S}, 59^{\circ} 12^{\prime} 30^{\prime \prime} \mathrm{W}\right)$ during April 1978 and March-June 1979. Man biting catches were performed in the manner described by Cahrlwood \& Wilkes (1979) with the exception that collections were made with aspirators when the numbers biting were very high.

A house, with a single occupant, situated at the edge of the village landing strip was used to study the insects house entering behaviour. The house was about I $\mathrm{km}$ from the village and approximately $25 \mathrm{~m}$ from the forest edge. In a series of paired catches an 'inside' collector sat within the cage-like front room of the house. This room consisted of a roof, one solid wall and three walls made up of $4 \mathrm{~cm}$ wide vertical bars with a gap between bars of approximately $4 \mathrm{~cm}$. During catches a $60 \mathrm{x}$ $50 \mathrm{~cm}$ window, facing away from the forest, was ieft open. The 'outside' collector sat $40 \mathrm{~m}$ from the house, parallel with it to the edge of the forest.

Paired collections were also made between this 'outside' position and the middle of the airstrip, circa $100 \mathrm{~m}$ from the forest edge.

(*) - Sunnybank Farm, Bolsterstone, Sheffield S 30 5ZL. England.

(*) - School of Biological Sciences, University of Sussex, Falmer, Brighton BNI 9QG. England. 
Collections were made between 17.30 and $19.30 \mathrm{~h}$. Collectors changed places on alternate collections.

In 1978 Polovodova's technique (Detinova, 1962) was used to determine the physiological age of biting females. This method was also used in 1979 to determine parity in some specimens.

\section{RESULTS}

A. triannulatus bachmanni bites predominantly at dusk with a reduced attack at dawn. In a series of all night biting catches less than $5 \%$ of the total A. triannulatus bachmanni caught were collected after $21.00 \mathrm{~h}$ (Charlwood \& Wilkes unpublished data). Figure I shows the biting activity at dusk in 1978 and 1979 collected by a human bait in the 'outside' position. Peak biting occurs only for a very restricted time.
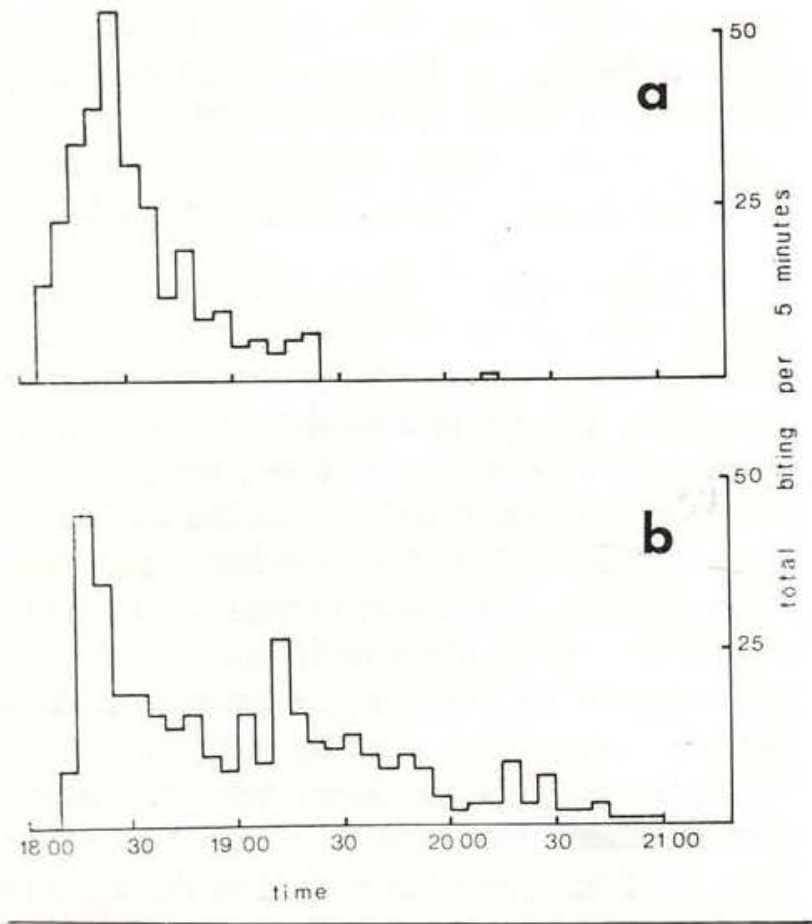

Figure 1 - Activity of $\mathbf{A}$. triannulatus bachmanni caught man biting in Aripuana. a) april 1978. b) June 1979.

The time of sunset has been corrected to 18.00 .

In all paired catches the great majority of insects were collected in the 'outside' position at the edge of the forest. The results of five 'inside',"outside' and four 'outside'/'airstrip' collections are given in Table I.

TABLE 1 - Results of paired 'outside'/'inside' biting catches $(n=5)$ and 'outside'/'airstrip' catches $(n=4)$ of Anopheles triannulatus bachmanni from Aripuana Brazil in June 1979.

\begin{tabular}{lrrrr}
\hline & Outside & Inside & Outside & Airstrip \\
\hline Number collected & 1193 & 50 & 757 & 98 \\
$\%$ of total & 95,8 & 4,2 & 88,5 & 11,5 \\
\hline
\end{tabular}

The age structure derived from dissections of 184 females collected in 1978 is given in Table 2. As with the A. darlingi Root dissected at the same time (Charlwood \& Wilkes 1979) the majority of the parous insects had well defined relics. This implies that the females had rested for at least twenty-four hours after oviposition. A survivorship curve, derived from the data (Figure 2) shows that mortality was more or less uniform between the different age groups.

Of 1177 adult females examined in June $1979,216(18.3 \%)$ were infected with an unidentified parasite resembling Coelomomyces sp.

TABLE 2 - Age composition of Anopheles triannulatus bachmanni collected man biting at Aripuana in April 1978.

Number of Dilatations

$\begin{array}{lllllll}0 & 1 & 2 & 3 & 4 & 5 & \text { Total }\end{array}$

Number

$\begin{array}{llllllll}\text { dissected } & 102 & 45 & 31 & 4 & 1 & 1 & 184\end{array}$ 


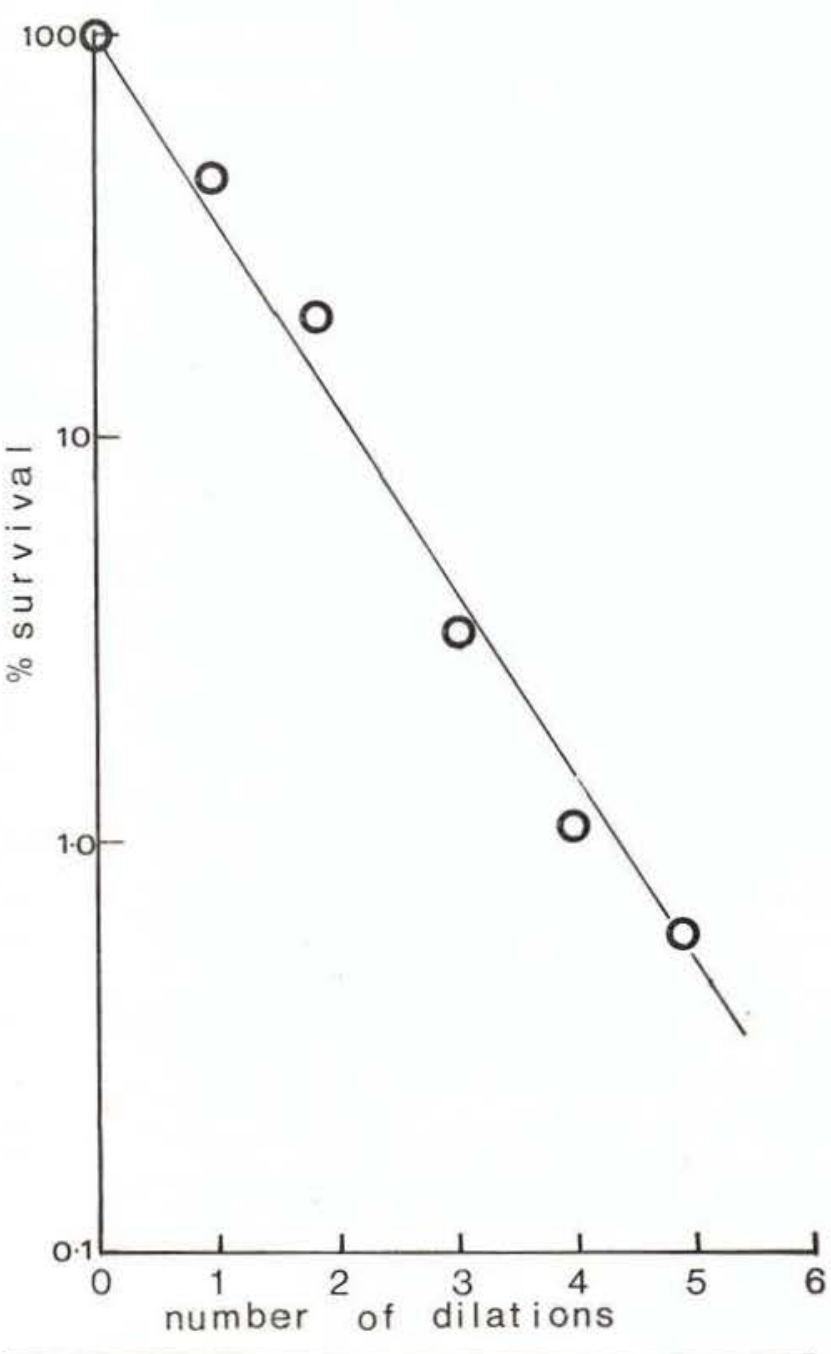

Figure 2 - Survival of A. triannulatus bachmanni collected in 1978.

\section{DISCUSSION}

The reluctance of $A$. triannulatus bachmanni to enter houses or to fly away from the forest edge indicates that this species is only likely to be of minor importance as a vector of malaria in Aripuana. Numbers biting and adult survivorship may, however, be sufficiently high for incidental transmission to occur. This possibility is enhanced by the fact that the peak biting activity takes place when many of the local inhabitants are outside their houses.

\section{ACKNOWLEDGEMENTS}

We would like to thank Dr. E. Salati and Dr. W. E. Kerr, Directors of I.N.P.A. in 1979 and 1978 for their support for this work and Altamiro Soares for assistance in the field. We are grateful to Dr. M. T. Gillies for his support and encouragement and for critically reading the manuscript.

\section{SUMÁRIO}

Foram coletados em Aripuanã, Mato Grosso, Anopheles triannulatus bachmanni com isca humana. Em capturas aos pares menos de $5 \%$ dos insetos foram coletados picando dentro de casas, a maioria dos insetos foram coletados nas margens da mata ao pôr do sol. A determinação fisiológica da idade indicou uma distribuição de idade uniforme de fêmeas, mas o comportamento do vôo dos insetos fá-los-ia de pouca importância como vetor da malária.

\section{REFERENCES}

ChARLWood, J.D. \& Wilkes, T.J.

1979 - Studies on the age composition of Anophe. les darlingi Root from Brazil. Bulletin of Entomological Research, 67: 337-342.

Covia-Garcia, P,

1951 - Distribucion geografica y datos bionomicos de los anofelinos de Venezuela. Pub. Div. de Malariol., 10: 1-352

DeAne, L.M.; Causey, O.R.; Deane, M.P.

1946 - Studies on Brazilian anophelines from the northeast and amazon regions. John Hopkins Press, Baltimore. 58 p.

DeAne, L.M. \& Ferreira Neto, J.A.

1973 - Malária de macacos no Estado de Goiás. Brasil: Encontro de guaribas, Alouatta caraya, infectados com Plasmodium brasilia. num. Rev. Inst. Med. Trop. São Paulo, 15: 107-111.

Detinova, T.S.

1962 - Age-grouping methods in Diptera of medical importance. Geneva (World Health Organiation: Monograph Series, N: 47).

ForatTINI, O.P.

1962 - Entomologia médica. São Paulo, Ed. Univ. de São Paulo. V. 1. 662 p.

Gorham, J.R.; Stojanovich, C.J.; SCOTt, H.G.

1967 - Clave illustrada para los mosquitos anofelinos de Sudamerica Oriental U. S. Department of Health, Education \& Welfare. Georgia. p. 64 .

(Aceito para publicação em $08 / 09 / 80$ ) 